\title{
De toekomst van de
}

\section{vennootschappelijk bestuurder: aan de bestuurstafel met een robot?}

\author{
Mr. A. van der $S_{p e k^{*}}$
}

\begin{abstract}
Artificial intelligence speelt een steeds grotere rol, zo ook binnen het ondernemingsrecht. In dit artikel staat de opkomst van de robot als vennootschappelijk bestuurder centraal. Daarbij wordt aandacht besteed aan rechtspersoonlijkheid, het functioneren van de robot als bestuurder en de aansprakelijkheid voor het handelen van de robotbestuurder.
\end{abstract}

\section{Inleiding}

'Robotrechter' en 'digitale rechtspraak' zijn termen die met enige regelmaat, al dan niet in positieve zin, in de krantenkoppen staan. ${ }^{1}$ Ook binnen het ondernemingsrecht schrijdt de technologie voort en begint kunstmatige intelligentie in toenemende mate een rol te spelen. Sommige bedrijven werken met artificial intelligence (AI)-systemen die grote hoeveelheden gegevens verwerken en bestuurders helpen om op deze manier beter geïnformeerd te zijn. In Hong Kong is inmiddels zelfs een vennootschap met een robot als vennootschappelijk bestuurder. ${ }^{2}$ Deze robot heeft, evenals alle andere bestuursleden, 'gewoon' een stem bij het nemen van bestuursbesluiten.

In Nederland loopt het zo'n vaart nog niet; het benoemen van een robot tot bestuurder is naar Nederlands recht (nog) niet mogelijk, nu in Nederland geldt dat (uitvoerende) bestuurders van een BV of een NV natuurlijke personen of rechtspersonen moeten zijn. ${ }^{3}$ Een robot voldoet niet aan deze eis. Desalniettemin heeft het Europees Parlement in 2017 een resolutie aangenomen waarin de Europese Commissie wordt aangespoord tot het verkennen van de optie om een specifieke rechtspersoonlijkheid te creëren voor robots. ${ }^{4}$ Met het toekennen van rechtspersoonlijkheid zou het in beginsel mogelijk

Mr. A. van der Spek is advocaat bij Florent te Amsterdam.

1. Hierover NRC Handelsblad, Robotrechter kan straks routinezaken behandelen, 29 september 2017; de Volkskrant, Is een robot als rechter daadwerkelijk objectiever?, 14 oktober 2017; NRC Handelsblad, Flop dreigt met digitale rechtspraak, 29 januari 2018; NRC Handelsblad, Debacle met digitale rechtspraak was voorzienbaar, 12 april 2018.

2. R. Wile, A venture capital firm just named an algorithm to its board of directors - Here's what it actually does, Business Insider 13 mei 2014 (www.businessinsider.com/vital-named-to-board-2014-5? international $=$ true\& $\mathrm{r}=\mathrm{US} \& \mathrm{IR}=\mathrm{T})$.

3. Zie art. 2:129a/239a lid 1 jo. art. 2:11 BW.

4. Resolutie van het Europees Parlement van 16 februari 2017 met aanbevelingen aan de Commissie over civielrechtelijke regels inzake robotica $(2015 / 2103(\mathrm{INL}))$ worden om een robot als vennootschappelijk bestuurder te benoemen. In deze bijdrage staan de vragen die met deze innovatie gepaard gaan centraal. Om de ontwikkelingen op het gebied van 'de robot als vennootschappelijk bestuurder' in een breder perspectief te plaatsen, zal in paragraaf 2 worden ingegaan op de Europese discussie met betrekking tot het toekennen van rechtspersoonlijkheid aan robots. Vervolgens wordt in paragraaf 3 beschreven waarom het functioneren van een robot als vennootschappelijk bestuurder van toegevoegde waarde kan zijn. Indien de mogelijkheid bestaat om een robot tot bestuurder te benoemen, roept dit ook de vraag op of de huidige regelgeving met betrekking tot bestuurdersaansprakelijkheid toegepast kan worden wanneer een robot onderdeel uitmaakt van de raad van bestuur. In paragraaf 4 wordt daarom aandacht besteed aan de ansprakelijkheid voor het handelen van de robotbestuurder. Tot slot wordt deze bijdrage afgesloten met de conclusie in paragraaf 5 .

\section{Rechtspersoonlijkheid voor robots}

\subsection{Het gesloten stelsel van rechtspersoonlijkheid}

In het Nederlandse rechtspersonenrecht geldt dat (uitvoerende) bestuurders van een $\mathrm{NV}$ of een $\mathrm{BV}$ zowel natuurlijke personen als rechtspersonen kunnen zijn. ${ }^{5}$ Het benoemen van een robot als bestuurder is dus in het huidige Nederlandse recht alleen mogelijk als een robot aangemerkt kan worden als een natuurlijke persoon, dan wel als een rechtspersoon.

Een natuurlijke persoon of een rechtspersoon is een drager van rechten en plichten en beschikt zelfstandig over de bekwaamheid om rechtshandelingen uit te voeren. ${ }^{6}$ Dat een robot niet kan worden aangemerkt als een natuurlijke persoon is evident. ${ }^{7}$ Een aantal karakteristieken van natuurlijke personen die te onderscheiden zijn van robots, zijn emotie, bewustzijn en het hebben van een vrije wil. ${ }^{8}$

5. Zie art. 2:129a/239a lid 1 jo. art. 2:11 BW.

6. S. de Schrijver \& R. van den Hoven van Genderen, I, robot: realiteit of fictie?, Computerrecht 2015/197.

7. L. Floridi \& J.W. Sanders, On the morality of artificial agents, Minds and Machines (14) 2004, afl. 3, p. 349-379.

8. R. van den Hoven van Genderen, AI-systemen en Robot als rechtspersoon, juridische noodzaak of begin van het einde?, MemoRad 2017, afl. 3, p. 27. 


\section{Maandblad \\ Ondernemingsrecht}

Bij de vraag of een robot als rechtspersoon kan worden aangemerkt, kan langer stilgestaan worden. Het uitgangspunt is dat het Nederlandse systeem van privaatrechtelijke rechtspersonen een gesloten stelsel is. ${ }^{9}$ Uit artikel 2:3 BW volgt welke entiteiten rechtspersoonlijkheid bezitten. Naast deze opsomming bestaat zowel voor de Europese als voor de Nederlandse wetgever de mogelijkheid om andere rechtspersonen te creëren. ${ }^{10}$ Ook in de rechtspraak zijn uitzonderingen op het gesloten stelsel zichtbaar. Zo werd in de jaren vijftig van de vorige eeuw in de rechtspraak al aangenomen dat een stichting rechtspersoonlijkheid bezat, alvorens dit wettelijk was vastgelegd. ${ }^{11}$ Ook tegenwoordig is het nog mogelijk dat er door de rechter rechtspersoonlijkheid wordt toegekend aan andere dan in artikel 2:3 BW genoemde subjecten. ${ }^{12}$ Daarbij dient te worden opgemerkt dat een beroep op het erkennen van rechtspersoonlijkheid niet snel gehonoreerd zal worden, met name omdat de wetgever twijfel zo veel mogelijk heeft willen uitsluiten. ${ }^{13}$ In zoverre kan dus niet worden gesproken van een strikt gesloten stelsel in het BW. De uitzonderingen op het gesloten stelsel hebben echter gemeen dat zij gecreëerd zijn door jurisprudentie. De vraag naar de mogelijkheid van een robot als rechtspersoon is tot op de dag van vandaag onaangeroerd gelaten in de jurisprudentie, bovendien zijn geen voorbeelden bekend waaruit blijkt dat er binnen het Nederlandse ondernemingsrecht robots als zelfstandig subject worden ingezet binnen de raad van bestuur. Dit makt dat binnen het huidige vennootschapsrecht geen aanknopingspunten bestaan om een robot als rechtspersoon aan te merken.

\subsection{Het toekennen van rechtspersoonlijkheid aan robots}

Een robot is een geprogrammeerd fysiek systeem, bestaande uit sensoren, bedieningselementen en stroomtoevoer, dat ertoe in staat is (semi)autonoom bepaalde taken uit te voeren. ${ }^{14}$ De robot is niet objectief, dit houdt in dat hij rekening houdt met de uitgangspunten die door de producent aan hem zijn meegegeven. De producent geeft de robot bepaalde input mee, die het fundament vormt voor verdere ontwikkelingen.

Om een robot als bestuurder te kunnen benoemen, zal eerst rechtspersoonlijkheid aan robots moeten worden toegekend. Geluiden in de literatuur tonen aan dat al langer nagedacht wordt over rechtspersoonlijkheid voor technologisch ontwikkelde systemen. Zo stelde Winter zichzelf al in 2001 de vraag of wij computersystemen op enig moment als rechtssubject zouden moeten gaan erkennen. Winter beschreef hierbij dat computers in een belangrijke mate afhankelijk zijn van

9. J.W. Winter, J.B. Wezeman \& J.D.M. Schoonbrood, Mr. P. van Schilfgaardes Van de BV en de NV, Deventer: Wolters Kluwer 2017, p. 17.

10. Asser/Maeijer \& Kroeze 2-I* 2015/42.

11. Wet op de stichtingen 1956. In de MvT bij deze wet (Kamerstukken II 1953/54, 3463, nr. 3, p. 1) wordt gesteld dat het gewoonterecht en de jurisprudentie waaraan het rechtsleven van de stichting thans bijna geheel onderworpen is, niet bij machte blijken om de geëigende rechtsregels te geven, en deze omstandigheid heeft geleid tot het ontwerp van een wettelijke regeling voor de stichting.

12. Asser/Maeijer \& Kroeze 2-I* 2015/42.

13. Asser/Maeijer \& Kroeze 2-I* 2015/42.

14. A. Ilachinski, AI, robots and swarms, CNA 2017, p. 7. menselijke inbreng en programmering, wat in essentie overeenkomt met de kenmerken van een robot, zoals hierboven omschreven. Winter merkte op dat het Nederlandse vennootschapsrecht zich moet openstellen voor de komst van digitale rechtspersonen en dat de computer als digitale rechtspersoon op eenzelfde wijze kan worden geconstrueerd als een rechtspersoon: de computer als digitale rechtspersoon, waarbij het handelen steeds tot een mens herleidbaar en toerekenbaar moet zijn. ${ }^{15}$ Desalniettemin is de echte discussie pas in februari 2017 aangewakkerd; ${ }^{16}$ op het moment dat het Europees Parlement een resolutie aanneemt en de Europese Commissie daarin verzoekt om:

'[o]p de lange termijn een specifieke rechtspersoonlijkheid te creëren voor robots, zodat in elk geval de meest geavanceerde autonome robots de status kunnen krijgen van elektronisch persoon die verantwoordelijk is voor het vergoeden van veroorzaakte schade'. ${ }^{17}$

Het Europees Parlement overweegt in de resolutie dat de huidige trend in de richting van de ontwikkeling van slimme, autonome machines zal gaan. Robots worden in toenemende mate autonomer, wat met zich brengt dat zij minder kunnen worden beschouwd als eenvoudige werktuigen die door andere actoren (de fabrikant, de eigenaar, de gebruiker) worden gehanteerd. Het is daarom volgens het Europees Parlement van essentieel belang dat de wetgevende macht alle gevolgen hiervan in aanmerking neemt. ${ }^{18}$

\subsection{Reacties op de resolutie}

Naar aanleiding van de resolutie heeft het Europees Economisch en Sociaal Comité (EESC) als 'vertegenwoordiger van het Europees maatschappelijk middenveld rondom AI' op 31 mei 2017 een advies gepubliceerd, waarin zeer terughoudend wordt gereageerd op het verzoek van het Europees Parlement. Het EESC stelt het volgende:

'Het EESC is tegen invoering van een vorm van rechtspersoonlijkheid voor robots of AI. De preventief corrigerende werking van het aansprakelijkheidsrecht wordt daarmee uitgehold, er ontstaat een moreel risico bij zowel de ont-

15. J.W. Winter, Vennootschapsrecht en moderne technologie, in: J.W Winter, R.E. van Esch \& G.J. van der Ziel, Afscheid van papier: handelsrecht en moderne technologie, Deventer: W.E.J. Tjeenk Willink 2001, p. 122-126.

16. Zie in dit verband bijv. J.B.S. Hijink, Robots in de boardroom, Ondernemingsrecht 2019/3, afl. 1, p. 10-17 en A. Bertolini \& G. Aiello, Robot companions: A legal and ethical analysis, The Information Society (34) 2018, afl. 3, p. 130-140.

17. Resolutie van het Europees Parlement van 16 februari 2017 met aanbevelingen aan de Commissie over civielrechtelijke regels inzake robotica (2015/2103 (INL)), p. 17-18. Er wordt in de resolutie niet nader ingegaan op de betekenis van het begrip 'specifieke rechtspersoonlijkheid'.

18. Zie 2015/2103 (INL), p. 5-6. 
wikkeling als het gebruik van AI en het biedt mogelijkheden tot misbruik.' 19

De aansporing om een specifieke rechtspersoonlijkheid te creëren, is ook door anderen ontvangen met kritiek. Zo hebben ruim 150 critici, onder wie geleerden op het gebied van AI, politieke leiders en experts op het gebied van ethiek in april 2018 een open brief gestuurd aan (onder anderen) de voorzitter van de Europese Commissie. ${ }^{20}$ De ondertekenaars van de brief stellen dat het toekennen van een 'specifieke persoonlijkheid' niet wenselijk is. Het grootste bezwaar dat de ondertekenaars aan de rechtspersoonlijkheid ten grondslag leggen, is dat er achter een robot niemand staat die aansprakelijk gehouden kan worden voor het handelen van de robot. In dit artikel wordt een zienswijze belicht waarin niet een persoon achter de robot aansprakelijk wordt gehouden, maar waarbij de robot zelf aansprakelijk zou kunnen zijn.

In april 2018 heeft de Europese Commissie als reactie op de resolutie een mededeling aan het Europees Parlement gedaan. ${ }^{21}$ De in deze mededeling gepresenteerde strategie van de Europese Commissie is gericht op het zo snel mogelijk gereed hebben van een alomvattend plan op het gebied van AI. In de mededeling is een aantal initiatieven op het gebied van robotisering aangekondigd, waaronder het instellen van een 'expertgroep' op het gebied van AI. ${ }^{22}$ Het onderwerp rechtspersoonlijkheid voor robots wordt niet aangekaart. De kern van de mededeling is er vooral in gelegen dat de Europese Unie koploper moet zijn wat betreft technologische ontwikkelingen op het gebied van AI. ${ }^{23}$ Aangezien China en de Verenigde Staten op dit gebied voorlopen, is het volgens de Commissie van groot belang om daadkracht te tonen en met Europa als geheel zo snel mogelijk vooruitgang te boeken. Wanneer niet op korte termijn veel geld en energie geïnvesteerd worden in de ontwikkeling en het gebruik van AI, loopt de Europese Unie het risico om geconfronteerd te worden met een braindrain en afhankelijk te worden van elders ontwikkelde technologieën op het gebied van AI. Aansluitend op de mededeling heeft de Europese Commissie in samenwerking met de lidstaten in december 2018 een actieplan opgesteld. ${ }^{24}$ In het actieplan worden de lidstaten aangespoord om met een strategie ter bevordering van het gebruik en de ontwikkeling van AI te komen.

19. EESC, Advies over kunstmatige intelligentie en de gevolgen van kunstmatige intelligentie voor de (digitale) eengemaakte markt, de productie, consumptie, werkgelegenheid en samenleving, 31 mei 2017 (INT/806), p. 4.

20. A.F.T. Winfield e.a., Open letter to the European Commission artificial intelligence and robotics, 2018. Zie www.robotics-openletter.eu/.

21. Europese Commissie, Mededeling van de Commissie 'Kunstmatige intelligentie voor Europa', 25 april 2018 (COM(2018)237 final).

22. Deze 'expertgroep' is op 29 oktober 2018 ingesteld en bestaat uit 52 experts op het gebied van AI. Zie https://ec.europa.eu/digital-\%20singlemarket/en/high-level-expert-group-artificial-intelligence.

23. Mededeling van de Europese Commissie van 25 april 2018 (COM(2018)237 final), p. 7.

24. Europese Commissie, Gecoördineerd plan op het gebied van kunstmatige intelligentie, 7 december 2018 (COM(2018)795 final).

\subsection{Boek niet voortijdig sluiten}

Aangezien de Europese Commissie tot op heden nog geen stelling heeft ingenomen met betrekking tot de vraag of er moet worden overgegaan tot het creëren van rechtspersoonlijkheid voor robots, is het aanlokkelijk om op grond van de hiervoor genoemde ethische bezwaren het boek voor de robot als bestuurder (voorlopig) te sluiten. Toch is het om twee redenen belangrijk dat de discussie met betrekking tot het vraagstuk of aan robots een vorm van rechtspersoonlijkheid moet worden toegekend, wordt voortgezet.

Allereerst is het van belang om over een vorm van rechtspersoonlijkheid voor robots na te denken, gezien het feit dat de ontwikkelingen in de praktijk zich in snel tempo opvolgen en de eerste robot zijn opwachting in de bestuurskamer al heeft gemaakt. Robot Vital is bij een rechtspersoon naar het recht van Hong Kong benoemd tot bestuurder. ${ }^{25}$ Zonder bekrachtiging van Vital is het de overige bestuurders niet toegestaan om investeringsbeslissingen te nemen. Dat de robotisering in de bestuurskamer binnen ons ondernemingsrechtelijke stelsel op een zeker moment in het verschiet ligt, is een kwestie waarmee juristen rekening moeten houden. Dat nog niet duidelijk is hoe de gewenste juridische structuur voor de robot als bestuurder eruit moet zien, is geen aanleiding om de discussie uit te stellen, maar juist een dringende reden om nu al na te denken over de inrichting van nieuwe wetgeving met betrekking tot het toekennen van een vorm van rechtssubjectiviteit aan robots.

Een tweede reden om over de rechtspersoonlijkheid van robots na te blijven denken, ligt in het verlengde van de reactie van de Europese Commissie. De technische ontwikkelingen volgen elkaar snel op en de nodige buitenlandse rechtsstelsels spelen hier al op in. Om de doelstellingen van de Europese Commissie te halen, en in Europees verband te streven naar het zijn van de koploper op het gebied van technologische ontwikkelingen binnen $\mathrm{AI}$, is het verstandiger om de discussie omtrent rechtspersoonlijkheid voor robots te continueren in plaats van een restrictieve houding aan te nemen. Hijink merkt hierbij op dat de wetten van regulatory competition, waarbij wetgevers met elkaar concurreren om het voor ondernemingen aantrekkelijk te maken om zich in het desbetreffende land te vestigen, per slot van rekening ook gelden voor de mogelijkheden tot het benoemen van een robot als bestuurder. ${ }^{26}$

\section{Het functioneren van de robot als vennootschappelijk bestuurder}

\subsection{Het functioneren van de robot}

$\mathrm{Bij}$ het produceren van een robot probeert de producent een deel van het menselijk brein te dupliceren, als gevolg waarvan

25. N. Burridge, Artificial intelligence gets a seat in the boardroom, 10 mei 2017 (https://asia.nikkei.com/Business/Artificial-intelligencegets-a-seat-in-the-boardroom).

26. Hijink 2019 


\section{Maandblad \\ Ondernemingsrecht}

de robot een vorm van cognitie komt te bezitten. ${ }^{27} \mathrm{Bij}$ deze technologie wordt vaak gebruikgemaakt van 'machine learning'. Dit is een vorm van AI die in staat is om aan de hand van het analyseren van data zichzelf te ontwikkelen en beslissingen te nemen die niet door de mens zijn geprogrammeerd. ${ }^{28} \mathrm{De}$ robot is niet objectief, dit houdt in dat hij rekening houdt met de inputdata die door de producent aan de robot zijn meegegeven. Op basis van de inputdata ontwikkelt de robot zich aan de hand van zelflerende algoritmes. Alvorens het zelflerende algoritme een niveau bereikt dat vergelijkbaar of beter is dan het niveau van het menselijk brein, dient het algoritme een ontwikkeling door te maken. Voor deze ontwikkeling is het noodzakelijk dat de robot een variëteit aan ervaringen opdoet. Pas na het opdoen van de noodzakelijke variëteit heeft de robot een juist beeld van de werkelijkheid. Een robot dient een leerproces te ondergaan, waarbij hij leert welk gedrag correct is. $\mathrm{Na}$ het maken van een grote hoeveelheid aaneengesloten keuzes, waarbij niet duidelijk is wat correct gedrag is en wat niet-correct gedrag is, wordt de robot 'beloond'. Ook die beloning is niet objectief, net zomin als de initiële input, en wordt bepaald door de producent van de robot. Op deze manier wordt het beeld van de werkelijkheid bijgesteld en wordt het algoritme geoptimaliseerd. ${ }^{29}$ Het streven van het algoritme is het genereren van een zo groot mogelijke beloning uit de autonoom gemaakte keuzes. Ter illustratie bij deze methode kan worden gedacht aan de ontwikkeling van zelfrijdende auto's; hier wordt bovenstaande methode onder meer op toegepast. De verkeerssituatie is een constant veranderende omgeving, waarin de beloning van het algoritme (aan de hand van het toekennen van punten) toeneemt bij het volgen van de verkeersregels en het voorkomen van ongevallen. ${ }^{30}$

Als gevolg van het leerproces waarbij de robot leert wat wel en wat geen correct gedrag is, leert hij patronen in verschillende fases herkennen. Op basis van enorme hoeveelheden aan data is de robot in staat om verbanden te leggen, nieuwe algemene regels te formuleren en statistische analyses te maken. Hoe meer data de robot tot zijn beschikking heeft, hoe meer dit de beslissing die de robot neemt ten goede komt. ${ }^{31}$ Het grenzeloos analyseren van data en het feilloos uitvoeren van routinezaken kan een robot vele malen beter en sneller dan een mens. In een vergelijkende test tussen twintig advocaten en de robot 'Law Geex Artificial Intelligence algorithm' werd het analytisch vermogen van beide partijen vergeleken. De robot scoorde aanzienlijk beter op het gebied van het maken van analyses, waarbij de accuratesse van de robot $94 \%$ was, tegenover gemid-

27. Het woord 'robot' is gebaseerd op het Tsjechische woord 'roboto' en betekent dienaar of slavenarbeid. De term stamt uit een toneelstuk uit 1920, waarin werd beschreven dat de maatschappij bediend wordt door harteloze, nagemaakte mensen.

28. M. Scheltema e.a., Whitepaper Juridische aspecten van AI \& machine learning, 2018, p. 2.

29. Scheltema e.a. 2018 , p. 3 .

30. Scheltema e.a. 2018 , p. 4.

31. A. Engelfriet, Wat zal artificial intelligence ons brengen in 2019?, 4 februari 2019 (www.advocatie.nl/correspondent-legal-tech-wat-zallegal-tech-ons-brengen-2019). deld $85 \%$ voor de advocaten. Hierbij kan tevens worden opgemerkt dat de advocaten gemiddeld 92 minuten voor de analyse nodig hadden, waar de robot zijn analyse binnen 26 seconden gereed had. ${ }^{32}$ Andere kwaliteiten van een robot zijn het zelfstandig vinden van patronen in datasets, het onderscheiden van patronen in datasets en het ontwikkelen van voorspellende modellen. ${ }^{33}$

\subsection{Enkele bestuurlijke kerntaken}

In de wet is in artikel 2:129/239 lid 1 BW te lezen dat het bestuur is belast met het besturen van de rechtspersoon. Wat vervolgens onder besturen dient te worden verstaan, vermeldt de wet niet. Het besturen van de vennootschap zou kunnen worden gedefinieerd als het zorg dragen voor het goed functioneren van de rechtspersoon en het voeren van de dagelijkse leiding over de rechtspersoon. ${ }^{34}$ Naast het leiding geven aan de dagelijkse gang van zaken is het bestuur belast met het maken van plannen voor de toekomst van de vennootschap. ${ }^{35}$ Een belangrijke taak van het bestuur waar ik op wijs, is dat het conform het statutaire doel de strategie van de onderneming bepaalt. ${ }^{36}$ In dit verband behoort het initiëren van beleidsafwegingen conform het vennootschappelijke doel tot de taak van het bestuur. ${ }^{37}$

Andere bestuurlijke taken zijn onder meer het adequaat beheren van beleggingen en het aantrekken van financiering voor activiteiten. Het bestuur dient de liquiditeit en solvabiliteit van de vennootschap daarbij te bewaken en het vermogen van de vennootschap, zo nodig in rechte, te beschermen. ${ }^{38}$

Tot slot is het bestuur verplicht op zodanige wijze een administratie te voeren van de vermogenstoestand, en de daartoe behorende boeken, bescheiden en andere gegevensdragers op zodanige wijze te bewaren, dat te allen tijde de rechten en verplichtingen van de rechtspersoon kunnen worden gekend. ${ }^{39}$ Dit houdt in dat op elk moment snel inzicht kan

32. Deze test is uitgevoerd door professoren van Duke University en Stanford University, de uitkomsten van deze test zijn vastgelegd in het rapport 'AI vs. Lawyers: The ultimate showdown', (www.lawgeex.com/ resources/aivslawyer/?

utm_source=google\&utm_medium $=$ cpc\&utm_campaign $=$ Global_sch brand\&utm_adgroup $=42250155000 \&$ device $=c \&$ placement $\& u t m \_t e r$ $\mathrm{m}=$ lawgeex\&gclid=EAIaIQobChMIkvGzoZOJ4gIVhs13Ch0uZgJHEA AYASABEgLlhPD_BwE).

33. Scheltema e.a. 2018, p. 5.

34. H. de Groot, Bestuurdersaansprakelijkheid, Deventer: Wolters Kluwer 2011, p. 20-21.

35. Van Schilfgaarde/De Winter, Wezeman \& Schoonbrood 2017, p. 180-181.

36. Het is aan het bestuur voorbehouden om de strategie van de vennootschap te bepalen. HR 21 januari 1955, ECLI:NL:HR:1955:AG2033 (Forumbank) en HR 13 juli 2007, ECLI:NL:HR:2007:BA7970 (ABN Amro).

37. J. Strikwerda, De Nederlandse Corporate Governance Code ingeleid, toegelicht en becommentarieerd, Amsterdam: Mediawerf Uitgevers 2018, p. 78.

38. M.J.G.C. Raaijmakers, Ondernemingsrecht, Deventer: Wolters Kluwer 2006, par. 4.6.

39. W.J. Slagter \& B.F. Assink, Compendium ondernemingsrecht, Deventer: Kluwer 2013, par. 51. 
worden verkregen in zowel de debiteuren- en crediteurenposities als de stand van de liquiditeit van de vennootschap. Bij het opstellen van de jaarrekening dient mede te worden gedacht aan het tijdig opmaken en het ter inzage leggen van de jaarrekening en het openbaar maken ervan conform de daarvoor geldende voorschriften.

De toenemende mate van 'robotisering' van de samenleving heeft tot gevolg dat mensen steeds meer taken over kunnen laten aan een robot. Dit geldt ook op het gebied van vennootschappelijke bestuurstaken. ${ }^{40}$ Door een robot in de bestuurskamer te laten plaatsnemen zouden enkele bestuurlijke taken, zoals hierboven beschreven, door de robot kunnen worden overgenomen. Hierbij valt te denken aan het monitoren van rapportages, het voeren van de vennootschappelijke administratie en het controleren van de jaarrekening. Het uitbesteden van dergelijke taken aan een robot als ondersteunend hulpmiddel zou nu al mogelijk zijn. Echter, wanneer de robot rechtspersoonlijkheid bezit en daadwerkelijk als bestuurder kan worden benoemd, zou dit meebrengen dat de robot op grond van bestuurdersaansprakelijkheid zelf aansprakelijk kan worden gehouden. Hier wordt in paragraaf 4 van dit artikel uitgebreider bij stilgestaan. Het overnemen van bepaalde bestuurstaken door de robot zou met zich meebrengen dat de overige bestuurders meer tijd verkrijgen om zich te concentreren op andere belangrijke bedrijfsaspecten, zoals de toekomstige strategie van de vennootschap. ${ }^{41}$

Hiermee is niet gezegd dat robots geen rol kunnen spelen op het gebied van vraagstukken rondom de strategie van de vennootschap. Integendeel, doordat een robot aan de hand van historische datasets verbanden kan ontdekken die voor natuurlijke personen niet meteen voor de hand liggen, kan een robot ook bij het nemen van beslissingen met betrekking tot het beleggen van gelden en het vormgeven van de geschikte acquisitiestrategie van grote meerwaarde zijn. ${ }^{42}$ Doordat een robot in staat is om binnen een kort tijdsbestek uitvoerige analyses te maken, kunnen factoren worden geïdentificeerd die cruciaal zijn voor het beoordelen en het voorspellen van marktonwikkelingen. In de praktijk blijkt dat bestuursleden niet altijd even goed thuis zijn in het vormgeven van de meest geschikte acquisitiestrategie. Een besluit tot overname is bijvoorbeeld een onderdeel van de acquisitiestrategie. Van alle overnames mislukt $65 \%$ tot $85 \%$, in die zin dat er geen waarde

40. G. van Solinge e.a., Toezicht. Voordrachten en discussieverslag van het gelijknamig congres van het Van der Heijden Instituut op 11 en 12 november 2017, Deventer: Wolters Kluwer 2018. Van Olffen stelt hierin dat AI zijns inziens al enige tijd geleden zijn intrede in de boardroom heeft gemaakt, nu er bij de voorbereiding en besluitvorming allang gebruikgemaakt wordt van de AI-techniek.

41. Zie over het voeren van de vennootschappelijke administratie: Het Financieele Dagblad, Robot neemt de boekencontrole voor zijn rekening, 23 juni 2018, p. 16.

42. Daily Mail, Would you take orders from a robot? An artificial intelligence becomes the world's first company director, 19 mei 2014 (www.dailymail.co.uk/sciencetech/article-2632920/Would-ordersROBOT-Artificial-intelligence-world-s-company-director-Japan.html). wordt gecreëerd. ${ }^{43}$ Een robot zou een meerwaarde kunnen zijn rondom de besluitvorming bij acquisities. Door een robot als bestuurder te betrekken bij de acquisitiestrategie zou het acquisitieproces gerichter en sneller kunnen worden uitgevoerd en kan systematisch gewerkt worden aan de waardevermeerdering van de onderneming.

Dat een robot binnen het bestuur kan bijdragen aan de interne risicobeheersings- en beoordelingssystemen, ${ }^{44}$ blijkt uit een voorbeeld uit de praktijk. ${ }^{45}$ In paragraaf 2.4 is al aangegeven dat robot Vital een plaats inneemt binnen het bestuur van Deep Knowledge Ventures (hierna: DKV), een rechtspersoon naar het recht van Hong Kong. DKV is begonnen als een traditioneel biotechnologiefonds, met een groot team van adviseurs en analisten die traditionele methoden gebruikten voor trend- en risicoanalyses. DKV analyseerde tientallen bedrijven, maar slaagde er niet in om patronen en risicofactoren te identificeren die het bedrijf succesvol moesten maken. Dit deed DKV op het idee komen een systeem te creëren dat in staat is grote hoeveelheden datasets te analyseren om patronen te onthullen en risico's te openbaren. De robot Vital werd gecreëerd en als gevolg hiervan konden niet tientallen, maar duizenden bedrijven worden geanalyseerd. Doordat meerdere bedrijven werden geanalyseerd, zijn factoren geïdentificeerd die cruciaal zijn voor het beoordelen en voorspellen van risico's. Zo toonde Vital aan dat de risico's op mislukkingen kleiner zijn in een bepaalde subsector. Naarmate dit feit duidelijker werd, is DKV zich gaan richten op deze subsector, hetgeen een succes bleek te zijn. De managing partner van DKV is van mening dat DKV niet meer zou hebben bestaan zonder Vital, omdat er mogelijk te veel geld geïnvesteerd zou zijn in projecten die geen waardevermeerdering zouden hebben opgeleverd. ${ }^{46}$ Gezien het succes van deze vorm van risicobeheersing, heeft Vital binnen het bestuur het recht om te bepalen of bepaalde investeringsrisico's genomen moeten worden of niet, en neemt het bestuur geen positief investeringsbesluit zonder toestemming van Vital. ${ }^{47}$

\section{De bestuurdersaansprakelijkheidsnorm toegepast op de robotbestuurder}

\subsection{Interne bestuurdersaansprakelijk op grond van artikel 2:9 BW}

Indien het mogelijk zou zijn om een robot als bestuurder te benoemen, roept dit nieuwe vragen op wat betreft de toepasbaarheid van huidige wet- en regelgeving met betrekking tot

43. E.J.J. Schenk, Fusies en acquisities. Fundamentele aspecten van fusies en acquisities, Amsterdam: Elsevier 2007, p. 67-139; E.J.J. Schenk, 65\% tot 85\% van de overnames mislukt, Het Financieele Dagblad 14 maart 2014.

44. Ingevolge principe 1.2 uit de Corporate Governance Code is het bestuur verantwoordelijk voor het beheersen van de risico's die aan de strategie en aan de activiteiten van de onderneming zijn verbonden. Op basis van de risicobeoordeling is het bestuur gehouden een risicobeheersings- en controlesysteem te implementeren en onderhouden.

45. Burridge 2017.

46. Burridge 2017

47. H. Koster, Blockchain, crypto finance en robotisering in het ondernemingsrecht, Ondernemingsrecht 2018/24, afl. 3, p. 153-154. 


\section{Maandblad}

Ondernemingsrecht

bestuurders. Een aspect daarvan is de vraag naar de aansprakelijkheid voor het handelen van de robot en de invloed die een mogelijke benoeming van een robot kan hebben op de aansprakelijkheid van de medebestuurders.

Ingevolge artikel 2:9 BW is elke bestuurder tegenover de vennootschap gehouden tot een behoorlijke taakvervulling. ${ }^{48}$ Tot de taak van alle bestuurders behoren de taken die niet aan afzonderlijke bestuurders toebedeeld zijn. ${ }^{49}$ Daarnaast draagt elke bestuurder verantwoordelijkheid voor de algemene gang van zaken. ${ }^{50}$ Voor de interne aansprakelijkheid ex artikel 2:9 $\mathrm{BW}$ is nodig dat minimaal één bestuurder onbehoorlijk heeft bestuurd en hem daarvan een ernstig verwijt kan worden gemaakt. ${ }^{51}$ De Hoge Raad heeft bepaald dat het handelen in strijd met een statutaire bepaling die strekt ter bescherming van de rechtspersoon, zoals het schenden van het goedkeuringsrecht van de raad van commissarissen, een zwaarwegende omstandigheid is bij de vaststelling van ernstig verwijtbaar handelen. ${ }^{52}$ Bovendien kan ernstig verwijtbaar handelen ook worden aangenomen indien het bestuur een te risicovol beleid kiest of beslissingen neemt zonder vooraf afdoende onderzoek te hebben gedaan naar de mogelijke risico's. ${ }^{53}$ In beginsel wordt dit gedrag vervolgens, vanwege de hoofdelijke aansprakelijkheid, aan het gehele bestuur toegerekend. ${ }^{54} \mathrm{Dit}$ is slechts anders indien een bestuurder, mede gelet op de taakverdeling, geen ernstig verwijt gemaakt kan worden en hij niet nalatig is geweest in het treffen van maatregelen om de gevolgen van het onbehoorlijk bestuur af te wenden.

\subsection{Ernstig verwijt: de geschikte maatstaf voor de robotbestuurder?}

In deze paragraaf wordt belicht hoe het ernstig-verwijtcriterium uitgelegd zou kunnen worden inzake het handelen of nalaten van een robotbestuurder. Hiertoe worden twee verschillende situaties beschreven.

48. In de MvT is neergelegd wat er onder een behoorlijke vervulling van de bestuurstaken moet worden verstaan: 'gehoudenheid van het bestuur tegenover de rechtspersoon tot een behoorlijke vervulling van de hem opgedragen taak'. Kamerstukken II 1980/81, 16631, nr. 3, p. 3.

49. Kamerstukken II 2008/09, 31763, nr. 3, p. 7 . Om te voorkomen dat taken die niet uitdrukkelijk zijn toebedeeld tussen wal en schip vallen, is er gekozen voor een negatieve formulering in art. 2:9 lid $1 \mathrm{BW}$.

50. Uit de wetsgeschiedenis blijkt niet duidelijk wat er onder de algemene gang van zaken geschaard kan worden. Wel wordt er in de literatuur betoogd dat het financiële en strategische beleid, overnames en beslissingen die samenhangen met risicobeleid kwesties zijn die onder de algemene gang van zaken vallen. Zie hierover A.J.P. Schild \& L. Timmerman, Het nieuwe art. 2:9 BW, uitgelegd voor gewone bestuurders, WPNR 2014, afl. 7011, p. 270-274.

51. Het ernstig-verwijtcriterium komt voort uit het arrest HR 10 januari 1997, ECLI:NL:HR:1997:ZC2243 (Staleman/Van de Ven) en is sinds 2013 in art. 2:9 lid 2 BW gecodificeerd.

52. HR 29 november 2002, ECLI:NL:PHR:2002:AE7011 (Schwandt/Berghuizer Papierfabriek).

53. Zo speelde in de Fortis-zaak de vraag of de aankoop van een belang in ABN Amro te risicovol was met het oog op de benodigde financiering. Hof Amsterdam (OK) 24 november 2008, ECLI:NL:GHAMS: 2008:BG5150 (Fortis), r.o. 3.10 en 3.15.

54. Slagter \& Assink 2013, par. 13.2.
De eerste situatie gaat uit van een 'fout' in het programma van de robot, waarbij de oorzaak van die fout te herleiden is tot een fout van een natuurlijke persoon. Hierbij kan worden gedacht aan de situatie waarbij achteraf blijkt dat de producent de robot niet volledig correct heeft geprogrammeerd, als gevolg waarvan de robot zijn taak niet met het juiste inzicht en de juiste zorgvuldigheid kan uitvoeren. ${ }^{55}$ Ook is het mogelijk dat de robot periodiek door de gebruiker geüpdatet moet worden om optimaal te functioneren. Wanneer de gebruikers, in dit geval de medebestuurders, nalaten de robot te updaten en de robot wel blijven gebruiken, is het mogelijk dat de robot beslissingen neemt op basis van incomplete informatie. Achteraf kan wellicht worden gesteld dat de robot over meer gegevens behoorde te beschikken en dat hij niet heeft gehandeld conform het inzicht en de zorgvuldigheid die van de robot mochten worden verwacht. In een dergelijk geval kan worden gesteld dat het verkeerd handelen van de robot voortkomt uit het niet-nakomen van de plicht van de medebestuurders. Het is dan niet ondenkbaar dat de robot zelf geen ernstig verwijt kan worden gemakkt.

De tweede situatie ziet op het geval dat de fout van de robot niet terug te voeren is op foutief menselijk handelen. Hierbij kan worden gedacht aan een autonome robot die op basis van zelflerende algoritmes beslissingen maakt. Dat de zelflerendheid van een robot nog niet altijd optimaal werkt, blijkt uit een studie waarbij onderzocht werd of een robot criminelen kan herkennen op basis van foto's. Gedurende deze studie zijn alle trainingsdata die de producent aan de robot heeft meegegeven wel correct, maar is achteraf gebleken dat de robot zichzelf verkeerde verbanden heeft aangeleerd. De trainingsdata bestonden onder andere uit verschillende foto's van criminelen en niet-criminelen. Nadat de robot met de foto's aan de haal ging, bleek de robot zichzelf op basis van het zelflerende algoritme een foute handeling aan te leren en verbond hij aan het dragen van een stropdas op de foto de conclusie dat de persoon op de getoonde foto geen crimineel was. ${ }^{56}$

Wanneer een dergelijke situatie analoog wordt toegepast op de robot als bestuurder, is het niet ondenkbaar dat de robot zichzelf een fout verband aanleert, hetgeen resulteert in het nemen van een verkeerde investeringsbeslissing, die achteraf bezien te risicovol was en niet genomen had mogen worden. Daarbij dient wel te worden opgemerkt dat over dergelijke beslissingen, net als bij beslissingen van 'gewone' bestuurders, veelal alleen met een bepaalde mate van hindsight bias geoordeeld kan worden. Als blijkt dat de trainingsdata compleet en correct zijn, zou er geen grond zijn om de persoon achter de robot, de producent, een verwijt te maken. Ook valt niet in te

55. Volgens Scheltema e.a. 2018, p. 5 houdt een robot alleen rekening met de belangen die de producent aan de robot meegeeft. Het optimaal uitvoeren van de aan de robot meegegeven taak is dus sterk afhankelijk van de op voorhand ingestelde opdracht.

56. L. Verhagen, Belangrijke beslissingen worden steeds vaker overgelaten aan slimme computers, de Volkskrant 23 november 2018 (www.volkskrant.nl/wetenschap/belangrijke-beslissingen-worden-steedsvaker-overgelaten-aan-slimme-computers $\sim \mathrm{b} 06 \mathrm{c} 2 \mathrm{e} 0 \mathrm{~d} /$ ). 
zien waarom het orgaan dat de robot als bestuurder heeft benoemd, aansprakelijk gehouden zou kunnen worden enkel vanwege het benoemen van de robot die verwijtbaar heeft gehandeld. Van een dergelijke mogelijkheid tot aansprakelijkstelling is namelijk ook geen sprake in het geval bij de benoeming van een natuurlijke persoon als bestuurder onder het huidige Boek 2 BW. In een dergelijk geval zou kunnen worden betoogd dat de robot een ernstig verwijt treft, nu hij niet conform de zorgvuldigheid die van een bestuurder die voor zijn taak berekend is, heeft gehandeld. In het kader van deze systematiek, waarbij de robot een ernstig verwijt gemaakt kan worden, is er ruimte om de robot zelf aansprakelijk te houden voor fouten die niet herleid kunnen worden tot fouten van anderen. De volgende vraag, die opkomt indien de robotbestuurder een ernstig verwijt treft, luidt: hoe dient de schade verhaald te worden?

\subsection{Het verhalen van de schade die de robotbestuurder dient te vergoeden}

Een mogelijke oplossing voor de vraag wie verantwoordelijk is voor de schade die veroorzaakt is door de autonome robotbestuurder, zou kunnen liggen in het afsluiten van een verplichte verzekering. Voor de invulling van deze verplichte verzekering kan aansluiting worden gezocht bij de verplichte verzekering zoals deze nu al geldt bij voertuigen. Het Europees Parlement benoemt deze mogelijke oplossing ook in de resolutie. ${ }^{57}$ Hierin stelt het Europees Parlement dat in een eventueel verzekeringssysteem voor robots rekening gehouden moet worden met alle potentiële verantwoordelijken in de keten. In de resolutie wordt dan ook aan de Europese Commissie verzocht om alle mogelijke oplossingen te verkennen, waaronder de optie waarbij de producent en de gebruiker of eigenaar van de robot verplicht worden een gezamenlijke verzekering af te sluiten voor eventuele schade die veroorzaakt wordt door de robot.

Om te waarborgen dat ook schadevergoedingen uitgekeerd kunnen worden als de verzekeraar de schade niet (volledig) kan voldoen, is het Europees Parlement van mening dat een dergelijk verzekeringssysteem, net als bij autoverzekeringen, gefinancierd zou kunnen worden uit een fonds. ${ }^{58}$ Dit compensatiefonds zou ofwel een algemeen fonds voor alle autonome robots kunnen zijn, ofwel een individueel fonds voor elke categorie robots, waaronder de robotbestuurder.

\subsection{En de medebestuurders?}

Een ander aspect is dat nu nog niet goed valt in te schatten wat het effect zal zijn van een onbehoorlijke taakvervulling van de robot als bestuurder en de wet- en regelgeving met betrekking tot de aansprakelijkheid van medebestuurders.

57. Resolutie van het Europees Parlement van 16 februari 2017 met aanbevelingen aan de Commissie over civielrechtelijke regels inzake robotica (2015/2103), p. 16.

58. Resolutie van het Europees Parlement van 16 februari 2017 met aanbevelingen aan de Commissie over civielrechtelijke regels inzake robotica (2015/2103), p. 17.
De wet biedt individuele bestuurders de mogelijkheid tot disculpatie. De mogelijkheid tot disculpatie is opgenomen om de soms verregaande gevolgen van aansprakelijkheid voor medebestuurders te beperken. De disculpatiemogelijkheid is daarmee een correctiemiddel voor onbillijke uitkomsten. ${ }^{59}$ Voor een geslaagd beroep op disculpatie moet een bestuur aantonen dat hem geen ernstig verwijt kan worden gemaakt. Daarnaast moet de bestuurder aantonen dat hij voldoende maatregelen heeft genomen om onbehoorlijk bestuur af te wenden. ${ }^{60} \mathrm{Bij}$ een beroep op disculpatie behoren alle omstandigheden van het geval in aanmerking te worden genomen. ${ }^{61}$ Dat in de praktijk weinig ruimte bestaat voor een geslaagd beroep op disculpatie, blijkt uit de jurisprudentie. Zo werd in de Landis-zaak als volgt geoordeeld:

'Een taakverdeling binnen het bestuur kan relevant zijn voor de vraag of een individuele bestuurder aansprakelijk is. Een takkverdeling brengt echter niet zonder meer mee dat bestuurders zich kunnen disculperen louter omdat zij andere taken hadden dan die welke onbehoorlijk werden vervuld. Ook ondanks een taakverdeling mag van een bestuurder van een vennootschap worden verwacht dat hij zich rekenschap geeft van de feiten en omstandigheden die van belang zijn voor (de gerechtvaardigdheid van) voorgenomen besluiten op het vlak van de kerntaken. ${ }^{62}$

Indien een robot plaatsneemt in de raad van bestuur en bepaalde taken toebedeeld krijgt, die hij vervolgens niet naar behoren uitvoert, als gevolg waarvan onbehoorlijk bestuur vast komt te staan, zou dit met de huidige strikte maatstaf meebrengen dat de overige bestuurders zich niet snel kunnen disculperen. Dit zou mutatis mutandis gelden indien de robot zich wil disculperen voor taken toebedeeld aan zijn medebestuurders. Zoals hierboven is weergegeven, bestaat in de praktijk weinig ruimte voor een geslaagd beroep op disculpatie en zal dit hoogstwaarschijnlijk niet veranderen wanneer een robot bepaalde bestuurstaken uitvoert. Ook in dit geval mag van de overige bestuurders worden verwacht dat zij zich laten voorlichten en dat er bij de ondertekening van stukken in verband met diverse transacties doorgevraagd dient te worden over de genoemde feiten en omstandigheden. ${ }^{63}$ Met de komst van een robot binnen het bestuur zou het voor bestuurders niet mogelijk moeten zijn om zich ter disculpatie achter de robot te verschuilen. Werkverdelingsafspraken tussen de robotbestuurder en de overige bestuurders nemen de algemene verantwoordelijkheid van iedere bestuurder voor het gevoerde beleid in beginsel niet weg. ${ }^{64}$ Dit brengt wel het paradoxale gevolg met zich dat het aanstellen van een robot als bestuurder

59. Slagter \& Assink 2013, par. 13.2 .

60. Kamerstukken II 2008/09, 31763, nr. 3, p. 8 .

61. HR 29 november 2002, ECLI:NL:PHR:2002:AE7011 (Schwandt/Berghuizer Papierfabriek).

62. Zie hierover Rb. Midden-Nederland 19 juni 2013, ECLI:NL:RBMNE: 2013:CA3225 (Landis), r.o. 9.19.5.

63. Hof Amsterdam 21 september 2010, ECLI:NL:GHAMS:2010:BN6929, r.o. 4.32.

64. Wezeman, in: GS Faillissementswet II.2.3.2.2 


\section{Maandblad}

Ondernemingsrecht

een lastenverzwaring oplevert voor de overige bestuurders, terwijl de robot aangesteld is met het idee de lasten deels uit handen te nemen.

\section{Conclusie}

In dit artikel is betoogd dat een robot kan bijdragen aan het bewerkstelligen van een deugdelijk stelsel waarbij het goed en verantwoord besturen van een vennootschap centraal staat. Een robotbestuurder is in staat risicofactoren en strategische kansen te analyseren die van invloed kunnen zijn op de strategie van een onderneming. Bovendien kan een robotbestuurder bijdragen aan het substantieel verbeteren en ondersteunen van beslissingsprocessen. Hiermee lijkt een robot veel noodzakelijke vaardigheden te bezitten waarover een bestuurder dient te beschikken. Dat er belangrijke vragen gepaard gaan met de vormgeving van de juridische structuur rondom een robot in de bestuurskamer en met het aansprakelijkheidsvraagstuk, is geen reden om het boek voor de robot als bestuurder voorlopig te sluiten. De toenemende mate van het gebruik van $\mathrm{AI}$ is juist een dringende reden om de discussie op dit gebied voort te zetten. 